\title{
L-ASCORBIC ACID DEGRADATION BY BACTERIA
} II. ADAPTIVE PROPERTIES TO L-ASCORBIC ACID

\author{
SHINTARO KAMIYA \\ Department of Agricultural Chemistry, Faculty of Agriculture, \\ Shizuoka University, Irwata, Shizuoka
}

(Received June 24, 1960)

In the previous paper (1), the author reported that L-ascorbic acid (L-AsA) (I) was mostly metabolized by an adaptive enzyme system of Micrococcus No. 4 through dehydroascorbic acid (DAsA) and diketo-L-gulonic acid to carbon dioxide and water, leaving a small amount of volatile acids. In unadapted cells, on the other hand, a constitutive enzyme catalyzing the dehydrogenation of AsA to DAsA was found to occur. It remains therefore to be settled whether the dehydrogenation proceeds by the AsA-oxidase or by another enzyme produced newly. This paper contains the results of the experiments performed to decide the above question. Further, the metabolism of D-araboascorbic acid (D-ArA) (II), an isomer of L-AsA, was investigated for clarifying the relationship between the structure of L-AsA and metabolism.

\section{EXPERIMENTAL AND RESULTS}

\section{Preparation of Cells}

Preparation of Unadapted Cells — To each of the three flasks with $20 \mathrm{ml}$ of $1 \%$ peptone liquid medium containing $1 \%$ glucose a loopful of the cells cultured previously on a peptone agar was inoculated. After incubation at $30^{\circ}$ for 2 days, the cells were collected by centrifugation, followed by washing twice with distilled water. After suspension in $1 / 15 M$ phosphate buffer, $\mathrm{pH} 5.2$, it was used for the experiment.

Preparation of L-AsA-Adapted Cells - The cells cultured in a medium containing L-AsA instead of glucose were treated similarly and suspended in $1 / 15 M$ phosphate buffer.

Preparation of D-ArA-Adapted Cells - The cells cultured in a medium containing $1 \% \mathrm{D}$-ArA instead of glucose were treated similarly. D-ArA used was synthesized by Ohle-Wolter's method (2). The sample obtained showed mp $171-2^{\circ}$. By paper chromatography, one spot, $R_{\mathrm{F}} 0.31$, was observed, using a solvent system: butanol: acetic acid: water $(4: 1: 1)$, and a color reagent: 2,6-dichlorophenol indophenol or $0.1 \%$ brom phenol blue.

\section{Manometric Method}

Manometric procedure was as follows. Main chamber: $2 \mathrm{ml}$ of 1/15 M phosphate buffer, pH 5.2, containing $15 \mu$ moles of the substrate; center well: 
$0.2 \mathrm{ml}$ of $15 \% \mathrm{KOH}$ or distilled water for determination of $\mathrm{CO}_{2}$; side bulb: $0.5 \mathrm{ml}$ of cell suspension (dry weight, $20 \mathrm{mg}$ ) in phosphate buffer, $\mathrm{pH} 5.3$. Reaction temperature: $30^{\circ}$.

Two controls were used, one was without L-AsA for measuring residual respiration of the cells and another contained the cells heated for $30 \mathrm{~min}$ at $100^{\circ}$ for determining the oxygen uptake due to autoxidation of L-AsA.

3. Decoloration of Nile Blue by Unadapted and Adapted Cells

Young (3) found it adequate to use Nile blue for determining the dehydrogenase activity of L-AsA-degrading bacterium. The author also used this dye for the decoloration activity of both unadapted and adapted cells. A solution of following components was placed in a Thunberg tube and after evacuation to $10 \mathrm{~mm} \mathrm{Hg}$, it was kept at $30^{\circ}$ in a thermostat. The time required for complete decoloration of the dye was determined: $2 \mathrm{ml}$ of phosphate beffer, $\mathrm{pH} 6.0$, containing $15 \mu$ moles of AsA, $1.0 \mathrm{ml}$ of $1 / 100,000$ Nile blue and $1.0 \mathrm{ml}$ of cell suspension (dry weight, $20 \mathrm{mg}$ ).

The L-AsA remaining after 8 hours were measured by indophenol method with the results given in Table I. In the adapted cells, the dye was completely decolored after $60 \mathrm{~min}$ and the L-AsA disappeared entirely after $8 \mathrm{hr}$. However, in the unadapted cells, the dye remained unchanged.

TABLE I

Decoloration of Nile Blue by L-Ascorbic Acid Bacterium

\begin{tabular}{ccc}
\hline Cell & Time for decoloration & Remaining $\mathrm{L}$-ascorbic acid \\
\hline Adapted & min & $\mu$ moles \\
Unadapted & 60 & 0 \\
\hline
\end{tabular}

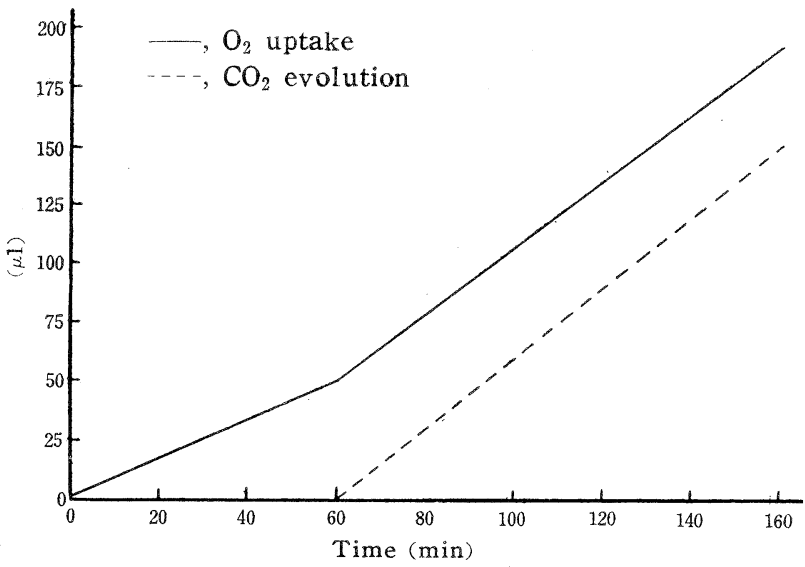

FIG. 1 Metabolism of L-Ascorbic Acid by the Adapted Cells
4. Loss and Reproduction of L-AsA-Degrading Activity of L-AsA-Adapted Cells

After leaving a suspension of the L-AsA-adapted cells in $1 / 15 M$ phosphate buffer, $\mathrm{pH} 5.3$, at $5^{\circ}$. for 7 days, L-AsA-degrading activity of the cells were examined manometrically. At an early stage of the degradation, as shown in Fig. 1, $\mathrm{O}_{2}$ uptake alone took place and after 1 hour $\mathrm{CO}_{2}$ evolution occurred sudden$1 y$. 
5. Degradation of $\mathrm{D}-A r A$ by $\mathrm{L}-A s A$ Adapted Cells

To clarify the relationship between chemical structure of L-AsA and degradation activity of the cells, degradation of D-ArA by both L-AsAadapted and unadapted cells and degradation of L-AsA by D-ArA-adapted cells were examined manometrical1y. As given in Figs. 2 and 3, the unadapted cells with D-ArA as a sulstrate showed a slight $\mathrm{O}_{2}$ uptake at the initial stage, but it stopped soon afterwards. Adapted cells for L-AsA or D-ArA, however, showed both marked $\mathrm{O}_{2}$ uptake and $\mathrm{CO}_{2}$ evolution. On the other hand, when D-ArA was used as a substrate, D-ArA-adapted cells failed to degrade L-AsA.

6. Degradation of 2-Keto-L-gluconic Acid and 2-Keto-D-gluconic Acid by LAsA-adapted Cells

As Fig. 4 shows, the unadapted

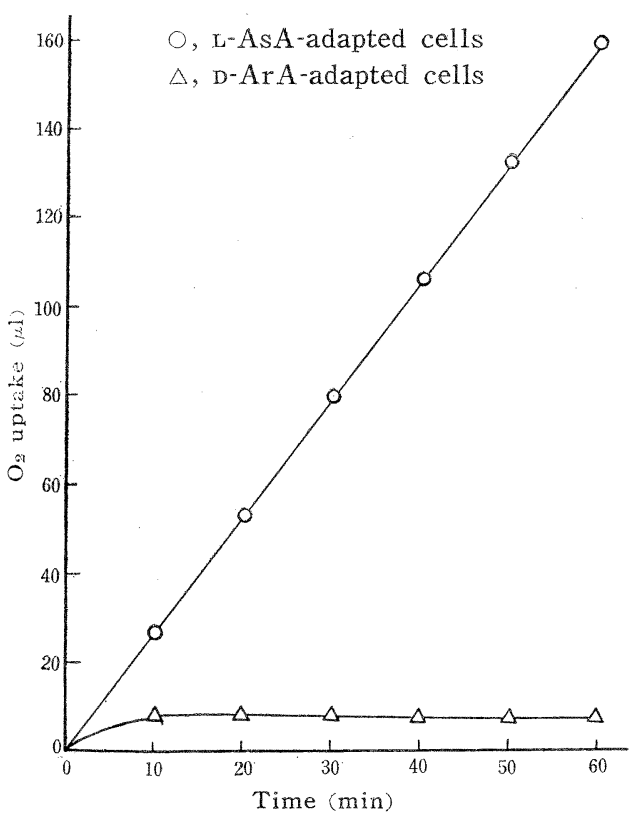

FIg. 3 Degradation of $\mathrm{L}$-Ascorbic Acid

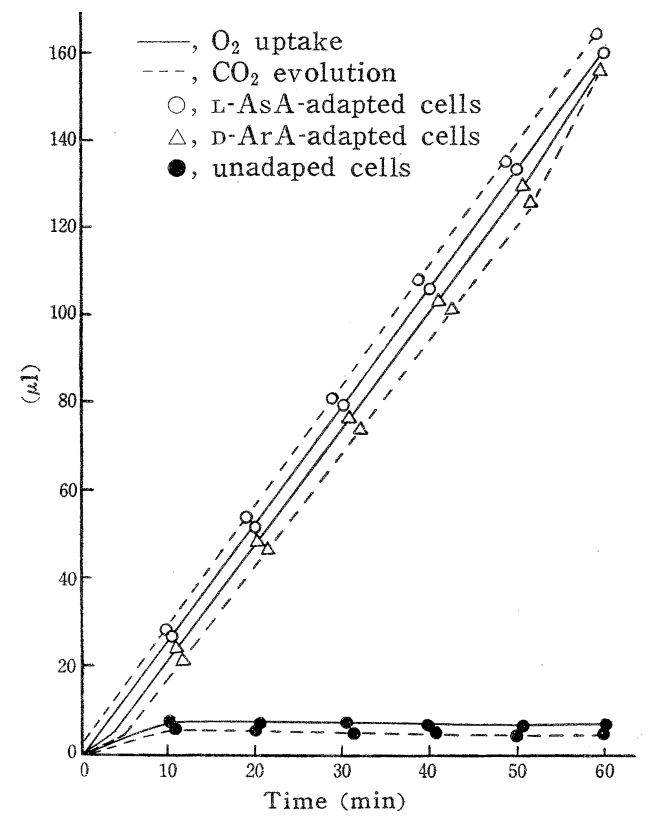

FIG. 2 Degradation of $\mathrm{D}$-Araboascorbic Acid

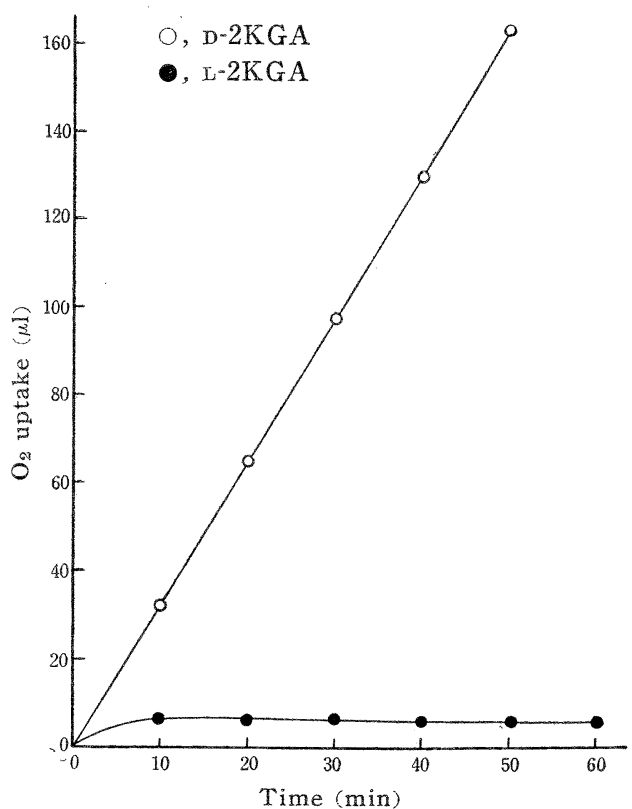

FIG. 4 Degradation of 2-Keto-D-gluconic and 2-Keto-L-gluconic Acid 
cells as well as those adapted for L-AsA or D-ArA degraded 2-keto-D-gluconic acid (IV) well, but failed to degrade 2-keto-L-gluconic acid (III).

\section{DISCUSSION}

From the behaviors of adapted and unadapted cells for Nile blue decoloration it is suggested that in the adapted cells a dehydrogenase system catalyzing a reaction $\mathrm{L}$-AsA $\rightarrow \mathrm{D}$-AsA is produced adaptively. Therefore, if both L-AsA oxidase and AsA dehydrogenase act simultaneously in the degradation of $\mathrm{L}$ -<smiles>O=C(O)C1OCOCC(C(O)CO)C1CO</smiles>

I. I-Ascorbic acid<smiles>O=C(O)C(O)C(O)C(O)CO</smiles>

III. 2-Keto-Lgulonic acid<smiles>O=C1COCC(O)C(O)C1C(O)CO</smiles>

II. D-Araboascorbic acid<smiles>O=C(O)C(O)C(O)C(O)CO</smiles>

IV. 2-Keto-Dgluconic acid

AsA by the adapted cells, the oxygen consumption should be the sum of both activities. However, practical1y equal amount of $\mathrm{CO}_{2}$ was produced to that of oxygen consumed, the participation of L-AsA oxidase is scarcely conceivable. If the adapted cells are allowed to stand for a long time without a substrate, it loses its activity, whereas the activity of LAsA oxidase reappears. If they are shaken for a certain time in the presence of AsA, the adaptive enzyme system is formed again and at the same time the activity of L-AsA oxidase disappears. On the other hand, the unadapted cells do not produce L-AsA adaptive enzyme even if they are shaken with L-AsA for a long time. The adaptive enzyme once formed, loses its activity gradually in the absence of the substrate without losing the factors or precursors essential for forming the enzyme system. Once the substrate is given, L-AsA adaptive enzyme system seems to be activated after a certain induction period.

As for the relationship between chemical structure of L-AsA and its degradation, as shown in Fig. 5, both L-AsA and D-ArA are metabolized by the L-AsA-adapted cells, whereas no degradation of L-AsA took place by the DArA-adapted cells. 2-Keto-D-gluconic acid is degradated by all the cells, both adapted and unadapted, whereas the $\mathrm{L}$-form remains unattacked. These results suggest the importance of the $\mathrm{L}$-form of $\mathrm{C}_{5}-\mathrm{OH}$ group and endiol structure of $\mathrm{C}_{2}$ and $\mathrm{C}_{3}$ for the production of $\mathrm{L}$-AsA adaptive enzyme. Further, the L-AsA oxidase in the unadapted cells is inactive for D-ArA, showing a specificity of the enzyme. 


\section{SUMMARY}

1. The reaction $\mathrm{L}$-ascorbic acid $\rightarrow \mathrm{D}$-dehydroascorbic acid by adapted and unadapted cells is catalyzed by different enzymes, i.e.. by L-ascorbic acid oxidase in the former and L-ascorbic acid dehydrogenase in the latter.

2. The adaptive enzyme system in L-ascobic acid-adapted cells was inactivated by standing without the substrate, but is reactivated by adding L-ascorbic acid.

3. The relationship between the chemical structure of L-ascorbic acid and its degradation by the cells was investigated.

\section{ACKNOWLEDGMEN'T}

The author is deeply indebted to Assistant Professor Dr. Toshio Nakabayashi for his kind guidance and support and also wishes to thank to Mr. Masataka Yamasaki, Tokyo Laboratory of Fujisawa Pharmaceutical Co., Ltd., for a gift of 2-keto-D-gulonic acid.

\section{REFERENCES}

1. Kamiya, S., J. Vitaminol. 6, 217 (1960).

2. Ohle, H., Wolter, R., Ber. 63, 843 (1930).

3. Young, R.M., Rettger, L. F., J. Bacteriol. 46, 351 (1943). 